\title{
THE HISTORY OF THE TREE SPARROW IN JAPAN BY FUMIO TAGUCHI
}

This is a most unusual book. The initial text in in Japanese, followed by a rather shorter English version, with 26 pages full of small colour illustrations and finally many pages of notes, the majority in Japanese but with some English translations. This review is based solely on the English text as I have no knowledge of Japanese. The book is written in an informal, conversational style which is perhaps a little unusual in a hard-back book and the author takes a very personal approach to the subject. His English is a little idiosyncratic but the meaning is usually apparent and I found it quite easy to read.

There are six chapters:

Chapter 1: Close relation between Man and the Tree Sparrow in Japan

Chapter 2: When the Tree Sparrow (Passer montanus) was recognized by people as the species as of today

Chapter 3: Tree Sparrow has deeply taken root in Japanese Culture

Chapter 4: There are two kinds of Passer in Japan

Chapter 5: Ecology of the Tree Sparrow in Japan

Chapter 6: Does the Tree Sparrow in Japan has future?

The author's main interest is in the place of the Tree Sparrow in Japanese culture. This takes up the greater part of the book and is the subject of virtually all of the illustrations. My knowledge of Japanese history, art and culture is extremely limited but I am interested in birds, and sparrows in particular, in European art and literature. I found much in the book to interest me. I have seen sparrows depicted in Japanese paintings but had no idea what an important role the Tree Sparrow has played in Japanese culture from an early period, though one needs to remember that as with "sparrow" in early English writing, "suzume" may originally have been used for any small sparrow-sized bird. In the early stories and legends the sparrows, and indeed the other birds and animals, often act like human beings. Some old folk tales like the Tongue Cut Sparrow include an element of cruelty as indeed we find in some of Grimms' Fairy Tales. It appears that the Tree Sparrows started to be noticed by the general population during the Edo Period (1605-1868). People started to feed them and provide gourds as nest boxes. The Tree Sparrow became one of the birds that appear in family crests and "suzume" occurs in various contexts such as place names, the names of shops, breweries and sweets. The Tree Sparrow is portrayed on netsuke, in various folk toys such as 
whistles and dolls and in ceramics as well as in paintings. Many examples are given in the delightful illustrations which are worth studying with a magnifying glass.

Chapter 4 is primarily concerned with the Tree Sparrow and the migratory, forest dwelling Cinnamon Sparrow Passer rutilans, the two species of sparrow found in Japan today, but there is also mention of the House Sparrow Passer domesticus, which occasionally occurs. An interesting nest box experiment carried out at Tomakomai Experimental Forest of Hokkaido University is described.

Chapter 5, the ecology of the Tree Sparrow in Japan, actually concerns the ornithologists who studied the Tree Sparrow, in particular Tominosuke Nibe (1882-1974) who wrote a 5 volume book, The Ecology of the Wild Bird which includes a number of references to sparrows. He undertook experimental work, some of which is described here.

In the final chapter, the author expresses his concern about the decline of the Tree Sparrow in Japan and suggests ways in which people can help it to survive. He also comments on the decline of the House Sparrow in London which he has witnessed on his occasional visits to the city.

This book is not for sale. Copies have been given to many of the leading bird organizations throughout the world. It contains much that will interest anyone who wants to learn about the place of the Tree Sparrow in Japanese culture. The copious references to historic and recent publications on the Tree Sparrow are probably of prime use to the Japanese readers or to those in other parts of the world with knowledge of the language. The book as published does not have an index but the author has now provided one.

Helen Baker 